\title{
Invasive plants - occurrence, importance and threat to biodiversity
}

\author{
Rośliny inwazyjne - występowanie, znaczenie \\ i zagrożenie dla bioróżnorodności
}

\author{
Krzysztof Domaradzki ${ }^{1}$, Adam Dobrzański ${ }^{2}$, Anna Jezierska-Domaradzka ${ }^{3}$
}

\begin{abstract}
Summary
The problem of alien invasive plant species that have been introduced to the environment voluntarily or accidently outside of their natural distribution area is discussed in this paper. In Europe total 5.789 species of plants are alien, while 1.017 occur in Poland. Not all alien plants are harmful to environment and only some of them are invasive and destructive. Invasive plants have been recently one of the major ecological problems. They cause serious ecological and economical impacts to ecosystems, particularly to agrophytocenosis. Invasive plants are also a threat for natural flora communities because they compete with native species for ecological niche and deeply modify functioning of ecosystems. The harmfulness of invasive species results in limitation of the biodiversity, decreasing the functionality of agricultural productive space, slowing down or blocking the succession processes as well as the change of physical and chemical soil properties. The limitation of negative influence of alien species should take into consideration several decisive factors. The most important is the evaluation of risk before introducing new species into environment, especially these that are used for energy and ornamental plants. The scale of threat, occurrence, distribution and spreading of invasive species should be recognized by monitoring. It is necessary to undertake actions aiming at limitation of occurrence and spreading as well as prevention by invasive species colonization.
\end{abstract}

Key words: invasive plants, occurrence, importance, threat, biodiversity

\section{Streszczenie}

Omówiono problem obcych gatunków roślin inwazyjnych wprowadzanych przez człowieka celowo lub przypadkowo do środowiska spoza naturalnych miejsc ich występowania. W Europie występuje 5789 gatunków roślin obcego pochodzenia, w Polsce 1017 taksonów. Nie wszystkie gatunki obce mają charakter inwazyjny i są szkodliwe dla środowiska. Rośliny inwazyjne są zagrożeniem dla flory naturalnych zbiorowisk, ponieważ konkurują z taksonami rodzimymi o niszę ekologiczną i znacząco modyfikują funkcjonowanie ekosystemu. Zagrożenie gatunkami inwazyjnymi jest obecnie zaliczane do ważniejszych, ekologicznych problemów. Mają one poważny wpływ na cały ekosystem, szczególnie na agrofitocenozę. Powodują też straty ekonomiczne. Ich szkodliwość polega na: ograniczeniu bioróżnorodności, zmniejszeniu funkcjonalności rolniczej przestrzeni produkcyjnej, spowalnianiu lub blokowaniu procesów sukcesji wtórnej oraz zmianach fizyko-chemicznych właściwości gleby i modyfikowaniu funkcjonowania ekosystemu. Ograniczenie negatywnego wpływu obcych gatunków powinno uwzględniać kilka decydujących czynników. Przed wprowadzaniem nowych gatunków do uprawy (zwłaszcza w przypadku roślin wykorzystywanych na cele energetyczne oraz roślin ozdobnych) najważniejsza jest ocena ryzyka. Rozmiar zagrożenia powinien być rozpoznany poprzez monitoring występowania i rozprzestrzeniania się gatunków inwazyjnych. Należy podjąć działania zmierzające do ograniczenia występowania, rozprzestrzeniania oraz zapobiegania kolonizacji przez gatunki inwazyjne.

Słowa kluczowe: rośliny inwazyjne, występowanie, znaczenie, zagrożenie, bioróżnorodność

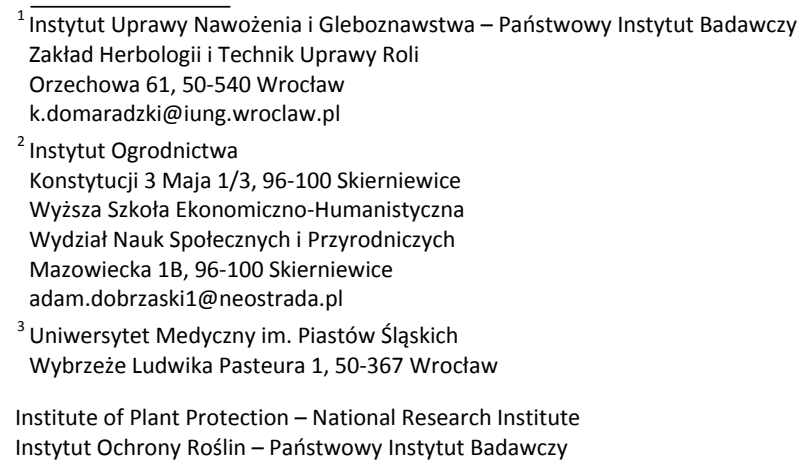




\section{Wstęp / Introduction}

Głównym wektorem rozprzestrzeniania się gatunków jest człowiek. Proces ten został zapoczątkowany w czasach historycznych, kiedy kupcy - przy okazji podróży handlowych - sprowadzali nowe, nieznane gatunki roślin i zwierząt. Działania te prowadzono na niewielką skalę i nie miały większego znaczenia. Przełomem był 15. i 16. wiek, kiedy rozpoczęły się wielkie podróże żeglarzy europejskich i dokonywane przez nich fundamentalne odkrycia geograficzne, jak np.: opłynięcie Przylądka Dobrej Nadziei przez Diasa (1488), dotarcie przez Kolumba do archipelagu Antyli u wybrzeży kontynentu amerykańskiego (1492), podróż Vasco da Gamy do Indii (1498), wyprawę Magellana dookoła świata (1519-1522), czy odkrycie Australii przez Portugalczyków (Favenc 2006; Wójcik 2006).

Późniejsza eksploracja nowoodkrytych ziem zaowocowała niespotykanym w dziejach przepływem różnych dóbr pomiędzy Starym a Nowym Światem. Wśród tych towarów znajdowały się również nieznane gatunki roślin, które sprowadzano celowo, jako rośliny użytkowe. W ten sposób europejska lista roślin uprawnych poszerzyła się o: ziemniaki, kukurydzę, pomidory, słonecznik i tytoń, natomiast do Ameryki trafiły: pszenica, żyto, owies, jęczmień i buraki. Nasiona i diaspory przenoszone były wraz z materiałem siewnym, paszą dla zwierząt, ziemią balastową, czy też materiałami pakunkowymi. Dostrzegano je zazwyczaj, gdy już się rozprzestrzeniły i dobrze zadomowiły na znacznych obszarach (Kornaś 1996). Niektóre introdukowane gatunki obce roślin, jak: kukurydza, pszenica, ryż oraz zwierząt, np.: drób, bydło i inne, są pożyteczne i zapewniają ponad $98 \%$ światowej produkcji żywności (Pimentel i wsp. 2001).

W opracowaniu zaprezentowano problem roślin inwazyjnych w rolniczej przestrzeni produkcyjnej, ze szczególnym uwzględnieniem ich występowania i ewentualnego zagrożenia dla roślin uprawnych.

\section{Charakterystyka inwazyjnych gatunków roślin i ich szkodliwości / Characteristic of invasive plant species and its harmfulnes}

Rośliny inwazyjne to gatunki o obcym pochodzeniu, które zadomowiły się na nowym obszarze, posiadające zdolność do rozmnażania się w nowych warunkach oraz do rozprzestrzeniania się (naturalnie lub z udziałem człowieka) na duże odległości od roślin matecznych. Gatunki te stanowią zagrożenie dla flory zbiorowisk danego obszaru, konkurując z taksonami rodzimymi o niszę ekologiczną, co może doprowadzić do całkowitego opanowania siedliska (Richardson i wsp. 2000; Pyšek i wsp. 2004) (rys. 1).

Ekspansywne gatunki roślin zawdzięczają dużą skuteczność w opanowywaniu nowych obszarów kilku podstawowym cechom (Kornaś 1996; Faliński 2004; Heywood i Brunel 2008) takim, jak:

- bardzo duża tolerancja na warunki siedliskowe i klimatyczne,
- łatwość rozmnażania generatywnego lub wegetatywnego, bardzo wysoki współczynnik reprodukcji w ciągu sezonu wegetacyjnego i długa żywotność nasion,

- szybki wzrost siewek, wczesna dojrzałość do reprodukcji i stosunkowo krótki cykl życiowy,

- proste i skuteczne rozprzestrzenianie się za pomocą wiatru, wody lub zwierząt,

- zdolność do krzyżowania się z innymi gatunkami, tworzenia poliploidów i ekotypów,

- szybki wzrost, pozwalający zagłuszyć i wypierać wolniej rosnące rośliny innych gatunków,

- niepohamowane rozprzestrzenianie, w warunkach braku naturalnych ograniczeń i wrogów.

Nie każdy gatunek inwazyjny musi charakteryzować się wszystkimi wymienionymi cechami, lecz im więcej ich posiada, tym może stanowić większe potencjalne zagrożenie. Nie zawsze jednak obcy gatunek pojawiający się na nowym dla niego obszarze, staje się inwazyjny. Zagadnienie to definiuje tzw. Reguła dziesiątek (ang. Tens rule), która mówi, że $\mathrm{z}$ dziesięciu gatunków introdukowanych świadomie lub przypadkowo na danym obszarze tylko jeden może wymknąć się spod kontroli. Z kolei tylko jeden z dziesięciu takich „uciekinierów” może podlegać procesowi naturalizacji, a najwyżej jeden $\mathrm{z}$ dziesięciu gatunków naturalizowanych można określić mianem inwazyjnego (Williamson i Fitter 1996).

Od tej reguły istnieją pewne odstępstwa, gdyż procesowi inwazji sprzyjają również czynniki zewnętrzne o charakterze lokalnym (Hulme 2005) takie, jak:

- modyfikacja lub degradacja siedlisk,

- fragmentacja ekosystemów,

- zaburzenia w bilansie wodnym i cyklu obiegu składników pokarmowych,

- nadużywanie środków chemicznych,

- porzucanie gruntów ornych,

a także globalnym, jak:

- powszechna globalizacja, minimalne uszczelnienie granic państwowych i szybki rozwój szlaków komunikacyjnych,

- zmiany klimatyczne.

Proces opanowywania nowych siedlisk o charakterze inwazji jest zjawiskiem długotrwałym. W życiu człowieka często jest on niedostrzegany, gdyż rozkłada się na kilka pokoleń. Kowarik (1995) twierdzi, że w warunkach Europy, w przypadku obcych gatunków krzewów trwa on około 130 lat, zaś drzew - około 170 lat.

Kolonizacja nowych obszarów przez gatunki inwazyjne przebiega w trzech etapach (Groves 1986) przez:

- introdukcję - polegającą na przeniesieniu materiału rozmnożeniowego (tzw. propagul) danego gatunku poza dotychczasowy obszar jego występowania i kończącą się powstaniem populacji osobników dorosłych;

- kolonizację - w czasie której pierwotna populacja osiaga zdolność do samoreplikacji i powiększania obszaru swego występowania;

- naturalizację - gdy gatunek tworzy nowe samoreplikujące się populacje podlegające szerokiemu rozprzestrzenianiu się i przenikające do naturalnych zbiorowisk. 
Szkody wyrządzane w ekosystemach przez gatunki inwazyjne (Marshall 2004; Vandermeer i Perfecto 2007) mogą być bardzo poważne i polegają głównie na:

- zubożeniu bioróżnorodności rodzimej flory i fauny,

- wnikaniu i szybkiej dominacji w zbiorowiskach naturalnych i półnaturalnych, co prowadzi do zjawiska „trywializacji szaty roślinnej”,

- zmianie fizyko-chemicznych właściwości gleby (akumulacja toksycznych allelopatyn, ujemny wpływ na obieg w glebie węgla i fosforu oraz zawartość azotu azotanowego, zmniejszenie trwałości agregatów glebowych, wzrost gęstości objętościowej gleby),

- ograniczeniu funkcjonalności gruntów rolnych, poprzez zarastanie brzegów rowów i koryt rzecznych lub znaczące ograniczenie plonowania roślin uprawnych,

- spowalnianiu lub blokowaniu procesów renaturalizacji i sukcesji wtórnej opuszczonych pól,

- osłabieniu funkcjonalności skrajów pól, co ma wpływ na zbiorowiska pożytecznych gatunków, w tym zapylaczy i drapieżników polujących na szkodniki.

\section{Gatunki obce w prawodawstwie międzynarodowym i polskim / Alien species in international and polish legislation}

O randze problemu i skali zagrożenia, jakie wywołują obce rośliny inwazyjne, świadczą dane Unii Europejskiej, według których straty przez nie powodowane w Europie wynoszą $3740 \mathrm{mln}$ euro rocznie (Kettunen i wsp. 2009). W Stanach Zjednoczonych Ameryki Północnej straty te sa szacowane na 27,9 mld \$, w Australii na 1,8 mld \$, w RPA na 1,5 mld $\$$, w Indiach na 37,8 mld $\$$, a w Brazylii na 17,0 mld \$ (Pimentel i wsp. 2001). W latach 70. XX wieku rozpoczęto dyskusje na forum międzynarodowym i opracowano pierwsze uregulowania $\mathrm{w}$ tym zakresie. Do podstawowych aktów prawnych należą: Konwencja Berneńska (Konwencja 1999), Konwencja z Rio de Janeiro (Konwencja 2002), Dyrektywa Siedliskowa Unii Europejskiej (Dyrektywa 1992), Kodeks postępowania w zakresie ogrodnictwa i inwazyjnych roślin obcych (Heywood i Brunel 2008).

Konwencja Berneńska o ochronie gatunków dzikiej flory i fauny europejskiej oraz ich siedlisk uchwalona została w roku 1979. Polska ratyfikowała Konwencję w 1995 r. Art. 11 ust. 2 lit. b wyżej wymienionego dokumentu mówi: „Każda z umawiających się stron podejmie się ściśle kontrolować introdukowanie gatunków obcych". W ramach Konwencji Berneńskiej przyjęto Europejską Strategię dotyczącą inwazyjnych gatunków obcych.

W roku 1992, w Rio de Janeiro podpisano kolejny dokument, a mianowicie Konwencję o różnorodności biologicznej, która została ratyfikowana przez Polskę w 1996 r. Art. 8 lit. h mówi: „Każda umawiająca się strona, w miarę możliwości i potrzeb zapobiega wprowadzaniu, kontroluje lub tępi te obce gatunki, które zagrażają ekosystemom, siedliskom lub gatunkom".
W tym samym czasie na forum Unii Europejskiej powstała tzw. Dyrektywa Siedliskowa $\mathrm{nr}$ 92/43/EWG z 21 maja 1992 roku, w sprawie ochrony siedlisk przyrodniczych oraz dzikiej fauny i flory. $\mathrm{W}$ art. 22 pkt 2 tego dokumentu widnieje następujący zapis: „Państwa członkowskie zapewniaja, aby celowe wprowadzenie do stanu dzikiego dowolnego gatunku, który nie jest rodzimy na ich terytorium, było uregulowane $\mathrm{w}$ taki sposób, by nie zaszkodzić siedliskom przyrodniczym w obrębie ich naturalnego zasięgu lub dzikiej rodzimej faunie i florze oraz, jeśli uznają to za konieczne, wprowadzają zakaz takiego wprowadzenia".

W naszym kraju podstawowym aktem prawnym jest Ustawa o ochronie przyrody z dnia 16 kwietnia $2004 \mathrm{r}$. (Dz. U. 2004 Nr 92, poz. 880), w której w art. 120, pkt 1 widnieje następujący zapis: „Zabrania się wprowadzania do środowiska przyrodniczego oraz przemieszczania w tym środowisku roślin, zwierząt lub grzybów gatunków obcych" (Ustawa 2004).

W Rozporządzeniu Ministra Środowiska z dnia 9 września 2011 r. (Dz. U. 2004, Nr 210, poz. 1260) w sprawie listy roślin i zwierząt gatunków obcych, które w przypadku uwolnienia do środowiska przyrodniczego mogą zagrozić gatunkom rodzimym lub siedliskom przyrodniczym wymienione zostały między innymi następujące gatunki obce: barszcz Sosnowskiego (Heracleum sosnowskyi) i barszcz Mantegazziego (H. mantegazzianum), bożodrzew gruczołkowaty (Ailanthus altissima), grubosz Helmsa (Crassula helmsii), kolcolist zachodni (Ulex europaeus), kolczurka klapowana (Echinocystis lobata), niecierpek pomarańczowy (Impatiens capensis), niecierpek gruczołowaty (I. glandulifera), rdestowiec ostrokończysty (Reynoutria japonica), rdestowiec sachaliński ( $R$. sachalinensis), rdestowiec czeski $(R . \times$ bohemica), trojeść amerykańska (Asclepias syriaca), tulejnik amerykański (Lysichiton americanum).

\section{Ryzyko introdukcji gatunków inwazyjnych przez uprawę roślin na cele energetyczne / Risk of the introduction of invasive species by the cultivation of plants to energy purposes}

Unia Europejska popiera, a nawet wymusza na krajach członkowskich, wykorzystywanie energii ze źródeł odnawialnych. W art. 3 Dyrektywy 2009/28/WE zawarty jest zapis mówiący o średnim udziale energii ze źródeł odnawialnych w całej wspólnocie na poziomie $20 \%$, w końcowym zużyciu energii brutto w 2020 r. W przypadku Polski wartość ta ma wynieść 15\%. Jednym ze źródeł energii jest spalanie biomasy. W wielu krajach Dyrektywa 2009/28/WE wymusza znaczące rozszerzenie uprawy roślin na cele energetyczne (Dyrektywa 2009).

Poza uprawianymi od dawna, a mogącymi służyć do pozyskiwania energii, wprowadza się gatunki nowe, obce dla rodzimej flory. Niestety, wiele $\mathrm{z}$ nich charakteryzuje się takimi samymi cechami, jak gatunki inwazyjne (Crosti 2010), a mianowicie:

- szeroką amplitudą ekologiczna,

- szybkim wzrostem i dużą produkcyjnością propagul oraz łatwością rozprzestrzeniania się, 
- brakiem naturalnych wrogów lub odpornością na szkodniki i choroby,

- zdolnością wymykania się z upraw.

Ponadto, cykl uprawy roślin $\mathrm{z}$ tej grupy użytkowej, również sprzyja ich rozprzestrzenianiu w ekosystemach. Zbioru tych roślin dokonuje się po przejściu przez nie pełnego cyklu rozwojowego, gdy rośliny zawierają jak najwięcej suchej masy. Sprzyja to wytworzeniu nasion lub innych propagul i ich dystrybucji zarówno w trakcie zbioru, transportu, jak i przechowywania. Gatunki roślin z przeznaczeniem na cele energetyczne powinny podlegać ocenie ryzyka inwazyjności przed wprowadzeniem ich do uprawy. W kilku krajach stosuje się już takie testy, które należy traktować jako narzędzie przesiewowe, pozwalające we wstępnym etapie ustrzec się wprowadzania do ekosystemu potencjalnie groźnych gatunków. Jednym z takich systemów służących do analizy oceny ryzyka jest opracowany w Szwajcarii test dla gatunków potencjalnie inwazyjnych na obszarze Europy Centralnej. Zaproponowano w jego ramach test walidacyjny oparty o analizę 12 odpowiednio punktowanych zagadnień (Weber i Gut 2004), w skład których wchodzą problemy:

1. Dostosowanie klimatyczne (0 lub $2 \mathrm{pkt}$ ).

2. Status danego gatunku w Europie (0 lub 2 pkt).

3. Geograficzne rozmieszczenie gatunku w Europie (1, 2 lub 3 pkt).

4. Zakres wielkości globalnego rozmieszczenia gatun$\mathrm{ku}$ (0 lub 3 pkt).

5. Doniesienia o występowaniu danego gatunku jako chwastu w innych rejonach (0 lub 3 pkt).

6. Taksonomia - czy gatunek posiada „krewnych” o charakterze chwastów (0 lub 3 pkt).

7. Żywotność nasion i reprodukcja (1,2 lub 3 pkt).

8. Wzrost wegetatywny $(0,1,2$ lub 4 pkt).

9. Sposób rozprzestrzeniania się gatunku $(0,1,2$ lub 4 pkt).

10. Forma życiowa (0, 2 lub 4 pkt).
11. Siedliska typowe dla danego gatunku (0 lub 3 pkt).

12. Gęstość populacji (0, 2 lub 4 pkt).

Podsumowanie punktów pozwala na zaklasyfikowanie danego gatunku do jednej z trzech klas ryzyka inwazyjności: 3-20 pkt - niskie ryzyko (gatunki o małym prawdopodobieństwie zagrożenia dla zbiorowisk naturalnych); 21-27 pkt - średnie ryzyko (gatunki wymagające dalszych badań i obserwacji); 28-39 pkt - wysokie ryzyko (gatunki o wysokim prawdopodobieństwie zagrożenia dla zbiorowisk naturalnych, jeśli zostały już naturalizowane). Przykłady wybranych gatunków inwazyjnych określonych na podstawie tego testu zawiera tabela 1.

W Instytucie Ochrony i Badań Środowiska we Włoszech, gdzie stosuje się modyfikację australijskiego systemu oceny ryzyka w zakresie chwastów wykazano, że spośród 15 skontrolowanych gatunków, zaproponowanych do upraw na cele energetyczne, co najmniej 9 posiada potencjał, aby stać się inwazyjnymi (Crosti 2010).

W Polsce, w celu pozyskiwania energii, można uprawiać: burak cukrowy, konopie, kukurydzę, len, rzepak, słonecznik, wierzbę wiciową, zboża i ziemniak, które nie stanowią zagrożeń dla rodzimej bioróżnorodności. Niestety propaguje się również od dawna znane w naszej florze ze swego inwazyjnego charakteru gatunki takie, jak: nawłoć kanadyjska (Solidago canadensis) i nawłoć późna (S. gigantea), czy też barszcz Sosnowskiego (H. sosnovskyi), rdestowiec sachaliński ( $R$. sachalinensis), rdestowiec ostrokończysty ( $R$. japonica), robinia akacjowa (Robinia pseudacacia), topinambur (słonecznik bulwiasty) (Helianthus tuberosus) (Rola i Rola 2010). Taksony te zaliczane są do najgroźniejszych obcych gatunków inwazyjnych w Polsce i jako takie nie powinny być świadomie namnażane, a wręcz przeciwnie należy ograniczać powierzchnię ich występowania (Anioł-Kwiatkowska i Śliwiński 2009; Dajdok i Pawlaczyk 2009; Rozporządzenie 2011).

Tabela 1. Ocena potencjalnej inwazyjności wybranych gatunków roślin na podstawie testu walidacyjnego (Weber i Gut 2004 zmieniona)

Table 1. Evaluation of invasive potential of selected plant species based on a validation test (Weber and Gut 2004 changed)

\begin{tabular}{l|l|c|c}
\multicolumn{1}{c|}{$\begin{array}{c}\text { Nazwa lacińska* } \\
\text { Scientific name }\end{array}$} & \multicolumn{1}{c|}{$\begin{array}{c}\text { Nazwa polska } \\
\text { Polish name }\end{array}$} & $\begin{array}{c}\text { Wynik sumaryczny } \\
\text { Sum }\end{array}$ & $\begin{array}{c}\text { Klasa ryzyka } \\
\text { Class of the risk }\end{array}$ \\
\hline Ailanthus altissima & bożodrzew gruczołkowaty & $\mathbf{3 9}$ & III \\
\hline Helianthus tuberosus & słonecznik bulwiasty & 39 & III \\
\hline Reynoutria japonica & rdestowiec ostrokończysty & III \\
\hline R. sachalinensis & rdestowiec sachaliński & $\mathbf{3 9}$ & III \\
\hline Solidago canadensis & nawłoć kanadyjska & 39 & III \\
\hline S. gigantea & nawłoć późna & 39 & III \\
\hline Heracleum mantegazzianum & barszcz Mantegazziego & $\mathbf{3 5}$ & III \\
\hline Rudbeckia laciniata & rudbekia naga & 35 & III \\
\hline Erigeron annuus & przymiotno białe & 31 & III \\
\hline Impatiens glandulifera & niecierpek gruczołowaty & $\mathbf{3 1}$ & III \\
\hline Galinsoga ciliata & żółtlica owłosiona & 26 & II \\
\hline Impatiens parviflora & niecierpek drobnokwiatowy & 25 & II \\
\hline
\end{tabular}

*gatunki podane pogrubionym drukiem wymieniono w Rozporządzeniu Ministra Środowiska z dnia 9 września 2011 - bold printed species are mentioned in Decree of Polish Ministry of Environment on September 9th 2011 


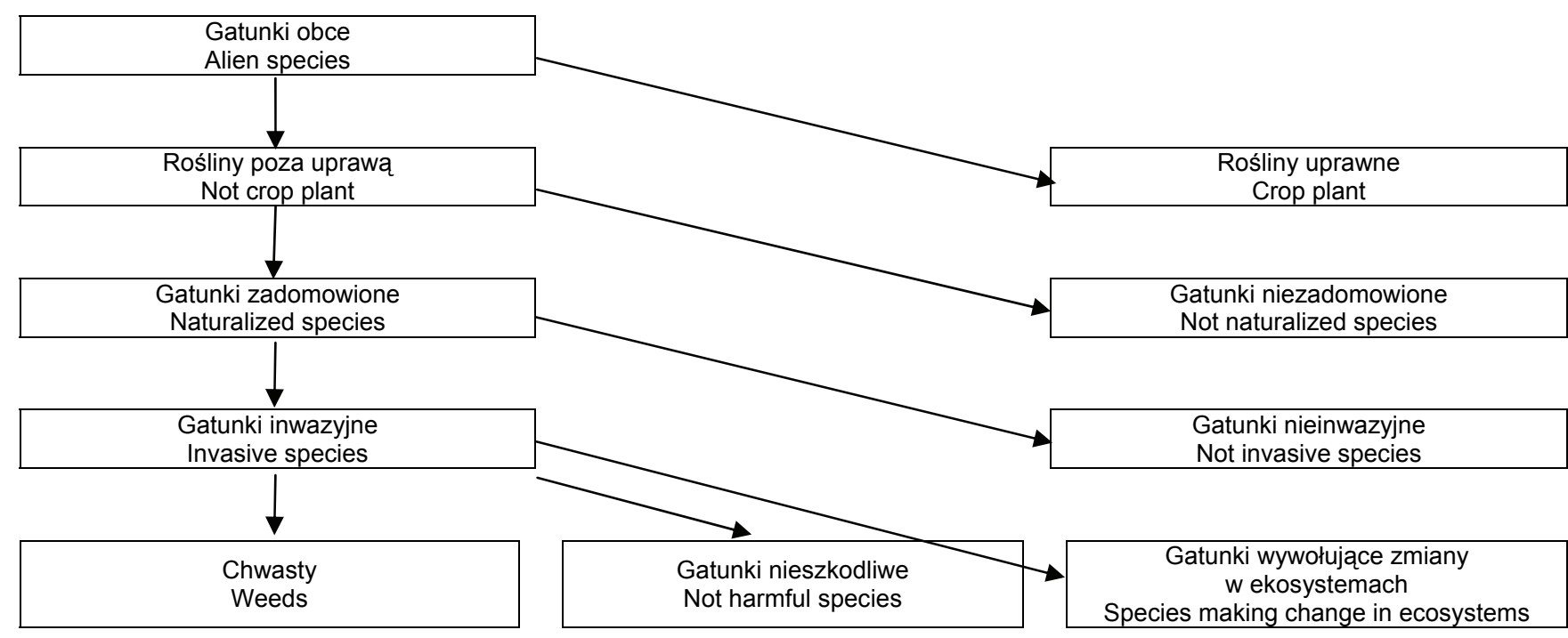

Rys. 1. Klasyfikacja gatunków inwazyjnych z uwzględnieniem ich znaczenia i końcowego umiejscowienia na nowych terenach (według Richardsona i wsp. 2000)

Fig 1. Classification of invasive species with taking into account their meaning and final situating on new areas (according to Richardson et al. 2000)

Od kilkunastu lat, na fali entuzjazmu spowodowanego rozwojem energetyki odnawialnej, propaguje się i wprowadza do uprawy nowe, potencjalnie groźne dla naszej flory gatunki takie, jak: ślazowiec pensylwański (Sida hermaphrodita), paulownia puszysta (Paulownia tomentosa), wieloletnie trawy: miskant olbrzymi (Miscanthus $\times$ giganteus), miskant cukrowy (M. sacchariflorus), spartina preriowa (Spartina pectinata) czy palczatka Gerarda (Andropogon gerardi) (Anioł-Kwiatkowska i Śliwiński 2009). Specyfika upraw roślin na cele energetyczne znacząco zwiększa prawdopodobieństwo przenikania tych gatunków do agroekosystemów. Może to być wynikiem „wymykania się z uprawy” lub świadomego porzucenia plantacji i pozostawienia jej bez kontroli (Crawley i wsp. 1996).

\section{Rośliny inwazyjne w przestrzeni rolniczej Invasive plants in agricultural space}

$\mathrm{Na}$ całym świecie inwazyjne gatunki obce zostały wprowadzone do rodzimych zbiorowisk w związku z działalnością rolniczą lub ogrodniczą. Były to dawne gatunki uprawne (rośliny rolnicze, warzywne, lecznicze, ozdobne), bądź inne taksony zawleczone $\mathrm{z}$ nimi przypadkowo. Szacuje się, że w Europie około 80\% gatunków inwazyjnych sprowadzono w ten sposób (Hulme 2007).

Gatunki obce łatwiej i szybciej opanowują fitocenozy niestabilne, a do takich należą siedliska synantropijne, w których zaburzone są mechanizmy ich funkcjonowania i naturalna struktura (Drake i wsp. 1989). W tej grupie, agroekosystemy, jako siedliska poddawane ciagłej presji i silnie zmienione przez człowieka, są najbardziej podatne na inwazje roślinne (Hulme 2005; Tokarska-Guzik i wsp. 2011). Oprócz pól uprawnych w przestrzeni rolniczej występują też użytki zielone, plantacje wieloletnie, nieużytki i odłogi oraz tereny przyległe (zadrzewienia i zakrzaczenia śródpolne, drogi i przydroża, a także tereny wokół budynków mieszkalnych i gospodarskich). Na tych obszarach również pod wpływem działalności człowieka mogą one także stać się siedliskiem dla gatunków obcego pochodzenia (Kołaczkowska 2008). Trudniej są opanowywane siedliska naturalne, o znikomej ingerencji człowieka, a proces ten może trwać nawet setki lat (Jackowiak 1999).

Pojawianie się roślin obcego pochodzenia w naszej florze nie jest zjawiskiem nowym. W Polsce, na 3554 gatunki roślin naczyniowych ogółem, aż 1017 taksonów, czyli 28\% charakteryzuje się obcym pochodzeniem (Tokarska-Guzik 2005). Dla porównania, w Europie obcym pochodzeniem legitymuje się 5789 gatunków, natomiast w Niemczech to 645 taksonów i 487 w Czechach (Kowarik 1999; Pyšek i wsp. 2002; Lambdon i wsp. 2008).

Tokarska-Guzik i wsp. (2010) w pracach dotyczących flory Wyżyny Śląskiej, spośród 1400 taksonów występujących ogółem, wyróżniają 20 gatunków chwastów (13 archeofitów i 7 neofitów) oraz 25 gatunków tzw. transformersów (wyłącznie neofitów), czyli gatunków mających wpływ na strukturę i charakter ekosystemów oraz wywołujących w nich zmiany. Wśród chwastów do neofitów zaliczono: Amaranthus retroflexus, Ambrosia artemisifolia, Conyza canadensis, Galinsoga ciliata, G. parviflora, Oxalis fontana i Veronica persica. W grupie transformersów wyróżniono kilka groźnych i ekspansywnych gatunków występujących w rolniczej przestrzeni produkcyjnej, tzn. na obrzeżach pól, przy drogach polnych, wokół zabudowań, czy na skrajach zadrzewień śródpolnych. Do grupy tej zaklasyfikowano m.in.: Bidens frondosa, Bunias orientalis, Epilobium adenocaulon, H. tuberosus, H. mantegazzianum, H. sosnovskyi, Impatiens glandulifera, I. parviflora, R. japonica, R. sachalinensis, $R . \times$ bohemica, Rudbeckia laciniata, Solidago canadensis i $S$. gigantea. Wiele z tych taksonów również w innych krajach europejskich zaliczanych jest do agresywnych gatunków inwazyjnych (Olaczek 1998; 
Kowarik 2002; Pyšek i wsp. 2002). Problem szkodliwości obcych gatunków inwazyjnych w skali naszego kraju i zagadnień związanych $\mathrm{z}$ zapobieganiem ich rozprzestrzeniania był już przedmiotem rozważań wielu autorów (Miklaszewska i Pagowska 2007; Solarz 2007; Pagowska i Lipa 2008; Nawrot 2009; Nawrot i Lipa 2012).

Na naszych polach również pojawiają się nowe, groźne gatunki chwastów. W ostatnich kilkunastu latach na plantacjach buraka cukrowego i kukurydzy oraz na ścierniskach po zbożach i rzepaku, a także na odłogach, obserwuje się występowanie Abuthilon theophrasti (Domaradzki i wsp. 2008). W niedalekiej przyszłości problemem dla rolników w Polsce mogą być dobrze znane w krajach sąsiedzkich groźne gatunki chwastów takie, jak: Sorgum halapense i Ambrosia artemisiifolia (Sowa i Warcholińska 1994; Szczę́niak 2004).

\section{Podsumowanie / Summation}

Otwartość granic i łatwość komunikacji sprzyja ekspansji gatunków inwazyjnych, których źródłem są najczęściej: materiał siewny, sprowadzane $\mathrm{z}$ zagranicy rozsady warzyw, rośliny ozdobne produkowane w pojemnikach. Oprócz nieprzemyślanej i rabunkowej dewastacji ekosystemów przez człowieka, to inwazje gatunki obce stanowią największe niebezpieczeństwo dla naturalnej bioróżnorodności (Genovesi i Shine 2003). Gatunki inwazyjne negatywnie wpływaja na rodzime składniki zbiorowisk roślinnych. W skrajnych przypadkach mogą doprowadzić do całkowitego zniszczenia naturalnej równowagi ekologicznej siedlisk (Faliński 2004). Ich obecność powoduje wymierne straty ekonomiczne dla światowej gospodarki. Ocenia się, że na Ziemi problem dotyczy 120000 gatunków, zarówno roślin, jak i zwierząt, na zwalczanie których rocznie wydaje się ponad 300 mld \$ (Pimental i wsp. 2007). W Europie straty powodowane przez rośliny inwazyjne szacuje się na 1,3 mld euro rocznie (Kettunen i wsp. 2009).

W celu ograniczenia tego niekorzystnego zjawiska należy dokonywać oceny ryzyka przed wprowadzaniem nowych gatunków do uprawy, zwłaszcza w przypadku roślin wykorzystywanych na cele energetyczne (Crosti
2010). Stałym elementem w zapobieganiu rozprzestrzenianiu się gatunków inwazyjnych powinien być monitoring, do czego obliguje „Konwencja o ochronie gatunków dzikiej flory i fauny europejskiej oraz ich siedlisk” (1999) oraz „Konwencja o różnorodności biologicznej" (1992). Regułą powinno być wczesne ich wykrywanie i szybkie eliminowanie. W Polsce nie ma wyspecjalizowanych służb zajmujących się jedynie monitoringiem rozprzestrzeniania się gatunków inwazyjnych, jak ma to miejsce $\mathrm{w}$ innych krajach, natomiast prowadzony jest Państwowy Monitoring Środowiska, którego celem jest obserwacja gatunków i siedlisk przyrodniczych, zwłaszcza cennych ze względu na ich unikatowość (Mróz 2010). Ten element powinien zostać jak najszybciej uzupełniony.

Ważne są również bezpośrednie działania mające na celu ograniczenie występowania oraz zapobieganie kolonizacji przez gatunki inwazyjne, do których należą wszelkie czynności zmierzające do zmniejszenia areału zajmowanego przez gatunki obce dla naszej flory, np. przez regularne koszenie lub punktowe niszczenie roślin w początkowej fazie kolonizacji, a także ograniczanie produkcji nasion i ich zdolności do kiełkowania przez mechaniczne usuwanie kwiatostanów i zbiór roślin przed uzyskaniem dojrzałości nasion. Ważne jest również ograniczenie przypadkowego rozprzestrzeniania się nasion (dokładne czyszczenie materiału siewnego i maszyn rolniczych). Ponadto istotne jest zmniejszenie powierzchni terenów mogących być potencjalnymi siedliskami dla gatunków inwazyjnych takich, jak obszary o naruszonej strukturze ekologicznej oraz grunty zdewastowane i porzucone. Należy unikać świadomego rozprzestrzeniania gatunków inwazyjnych i stosowania ich w publicznych nasadzeniach na dużą skalę, pamiętając o tym, że wiele uciążliwych taksonów sprowadzono do ogrodów botanicznych, jako rośliny ozdobne.

W ograniczaniu ekspansji tej grupy roślin może pomóc szkolenie pracowników służb doradczych i rolników. Pozwoli to kształtować świadomość tej grupy naszego społeczeństwa, wskazywać im zagrożenia dla agrofitocenoz i otaczającego nas środowiska.

\section{Literatura / References}

Anioł-Kwiatkowska J., Śliwiński M. 2009. Obce rośliny energetyczne - zagrożenie dla flory Polski. Pam. Puł. 150: 35-44.

Crawley M.J., Harvey P.H., Purvis A. 1996. Comparative ecology of the native and alien floras of the British Isles. Philosophical Transactions of the Royal Society 351: 1251-1259.

Crosti R. 2010. Inwazyjność upraw przeznaczonych na produkcję biopaliw i potencjalne szkody wyrządzane naturalnym siedliskom i gatunkom rodzimym. Raport Stałego Komitetu UE, 31 ss.

Dajdok Z., Pawlaczyk P. (red.). 2009. Inwazyjne gatunki ekosystemów mokradłowych Polski. Wyd. Klubu Przyrodników, Świebodzin, $167 \mathrm{ss}$.

Domaradzki K., Snopczyński T., Jezierska-Domaradzka A. 2008. Zaślaz pospolity (Abutilon theophrasti Medik.), nowy groźny chwast upraw polowych - charakterystyka występowanie i możliwości zwalczania. [Abutilon theophrasti Medik., new dangerous weed characterization, appearance and control possibilities]. Prog. Plant Prot./Post. Ochr. Roślin 48 (2): 567-574.

Drake J.A., di Castri F., Groves R.H., Kruger F.J., Mooney H.A., Rejmánek M., Williamson M. (eds). 1989. Biological Invasions. A Global Perspective. Published for the Scientific Committee on Problems of the Environment, International Council of Scientific Unions, by Wiley, Chichester, 525 pp.

Dyrektywa Parlamentu Europejskiego i Rady 2009/28/WE z dnia 23 kwietnia 2009 r. w sprawie promowania stosowania energii ze źródeł odnawialnych. Dziennik Urzędowy Unii Europejskiej, L 140/16. 
Dyrektywa Rady 92/43/EWG z dnia 21 maja 1992 r. w sprawie ochrony siedlisk przyrodniczych oraz dzikiej fauny i flory. Dziennik Urzędowy Wspólnot Europejskich, L 206/7.

Faliński J.B. 2004. Inwazje w świecie roślin: mechanizmy, zagrożenia, projekt badań. Phytocoenosis 10 (N.S.), Seminarium Geobotanicum 16: 3-31.

Favenc E. 2006. The History of Australian Exploration from 1788 to 1888. Echo Library: 2-4.

Genovesi P., Shine C. 2003. European Strategy on Invasive Alien Species. Convention on the Conservation of European Wildlife and Natural Habitats Standing Committee, Strasbourg, 68 pp.

Groves R.H. 1986. Invasion of mediterranean ecosystems by weeds. p. 129-145. In: "Resilience in Mediterranean-Type Ecosystem" (B. Dell, A.J.M. Hopkins, B.B. Lamont, eds). Junk, Dordrecht, 68 pp.

Heywood V., Brunel S. 2008. Kodeks postępowania w zakresie ogrodnictwa i inwazyjnych roślin obcych. [Code of conduct on horticulture and invasive alien plants]. Publikacje Rady Europy, Przyroda i Środowisko 155, 52 ss.

Hulme P.E. 2005. Nursery crime: agriculture as victim and perpetrator in the spread of invasive species. Crop Sci. Technol., British Crop Prot. Council: 733-740.

Hulme P.E. 2007. Biological invasions in Europe: drivers, pressures, states, impacts and responses. p. 56-80. In: "Biodiversity under Threat" (R. Hester, R.M. Harrison, eds). Environ. Sci. Technol. 25, 290 pp.

Jackowiak B. 1999. Modele ekspansji roślin synantropijnych i transgenicznych. Phytocoenosis 11, Seminarium Geobotanicum 6: 4-16.

Kettunen M., Genovesi P., Gollasch S., Pagad S., Starfinger U., Ten Brink P., Shine C. 2009. Technical support to EU strategy on invasive species (IAS) - Assessment of the impact of IAS in Europe and the EU (Final draft report for the European Commission). Institute for European Environmental Policy (IEEP), Brussels, Belgium, $131 \mathrm{pp}$.

Kołaczkowska E. 2008. Inwazje gatunków obcych roślin - problem naukowy i praktyczny. Przegląd Geograficzny 80 (1): 55-73.

Konwencja o ochronie gatunków dzikiej flory i fauny europejskiej oraz ich siedlisk. 1999. Wyd. Naukowe PWN, Warszawa, 35 ss.

Konwencja o różnorodności biologicznej, sporządzona w Rio de Janeiro dnia 5 czerwca 1992 r., Dz. U. 2002 Nr 184, poz. 1532.

Kornaś J. 1996. Pięć wieków wymiany flor synantropijnych między Starym i Nowym Światem. Wiadomości Botaniczne 40 (1): 11-19.

Kowarik I. 1995. Time lags in biological invasions with regard to the success and failure of alien species. p. 15-38. In: "Plant Invasions - General Aspects and Special Problems" (P. Pyšek, K. Prach, M. Rejmánek, P.M. Wade, eds). SPB Academic Publishing, Amsterdam, $263 \mathrm{pp}$.

Kowarik I. 1999. Neophytes in Germany: quantitative overview, introduction and dispersal pathways, ecological consequences, and open questions. p. 12-36. In: Alien Organisms in Germany. Documentation of a Conference, Legal Regulations Concerning Alien Organisms in Comparison to Genetically Modified Organisms. Berlin, 5-6 March 1998, Federal Environmental Agency 18, 142 pp.

Kowarik I. 2002. Biologische Invasionen in Deutschland: zur Rolle nichteinheimischer Pflanzen. p. 5-24. In: Biologische Invasionen. Herausforderung zum Handeln? (I. Kowarik, U. Starfinger, eds). Neobiota 1, 377 pp.

Lambdon P.W., Pyšek P., Basnou C., Hejda M., Arianoutsou M., Essl F., Jarošík V., Pergl J., Winter M., Anastasiu P., Andriopoulos P., Bayos I., Brundu G., Celesti-Grapow L., Chassot P., Delipetrou P., Josefsson M., Kark S., Klotz S., Kokkoris Y., Kühn I., Marchante H., Perglová I., Pino J., Vilà M., Yikos A., Roy D., Hulme P.E. 2008. Alien flora of Europe: species diversity, temporal trends, geographical patterns and research needs. Preslia 80: 101-149.

Marshall E.J. 2004. Agricultural landscapes. J. Crop Improvement 12 (1-2): 365-404.

Miklaszewska K., Pagowska E. 2007. Problem roślinnych gatunków inwazyjnych w Polsce. [Problem of invasive alien plant species in Poland]. Prog. Plant Prot./Post. Ochr. Roślin 47 (1): 84-87.

Mróz W. (red.). 2010. Monitoring siedlisk przyrodniczych. Przewodnik metodyczny. Cz. 1. Biblioteka Monitoringu Środowiska, Warszawa, $311 \mathrm{ss}$.

Nawrot J. 2009. Problem obcych gatunków inwazyjnych dla ochrony roślin. [Significance of invasive alien species for plant protection]. Prog. Plant Prot./Post. Ochr. Roślin 49 (3): 1150-1154.

Nawrot J., Lipa J.J. 2012. Znaczenie obcych gatunków inwazyjnych w ochronie roślin. [Significance of invasive alien species in plant protection]. Prog. Plant Prot./Post. Ochr. Roślin 52 (2): 449-452.

Olaczek R. 1998. The synanthropization of plant cover in the protected areas as a scientific and conservation problem. p. 275-279. In: Synanthropization of plant cover in new Polish research (J.B. Faliński, W. Adamowski, B. Jackowiak, red.). Phytocoenosis 10 (N.S.), Supplementum Cartographiae Geobotanicae 9, 279 pp.

Pagowska E., Lipa J.J. 2008. Dobrowolne kodeksy dobrej praktyki jako środki ograniczające rozprzestrzenianie się obcych gatunków inwazyjnych i kwarantannowych. [Voluntary codes of conduct as means limiting the spread of invasive alien species and quarantine pests]. Prog. Plant Prot./Post. Ochr. Roślin 48 (1): 47-51.

Pimentel D., McNair S., Janecka J., Wightman J., Simmonds C., O’Connell C., Wong E., Russel L., Zern J., Aquino T., Tsomondo T. 2001. Economic and environmental threats of alien plant, animal, and microbe invasions. Agriculture, Ecosystems and Environment 84: $1-20$

Pimental D., Pimental M., Wilson A. 2007. Plant, animal, and microbe invasive species in the United States and world. p. 315-330. In: "Biological Invasions" (W. Nentwig, ed.). Ecological Studies 193, Springer-Verlag, 441 pp.

Pyšek P., Sádlo J., Mandák B. 2002. Catalogue of alien plants of the Czech Republic. Preslia 74: 97-186.

Pyšek P., Richardson D.M., Rejmánek M., Webster G.L., Williamson M., Kirschner J. 2004. Alien plants in checklists and floras: towards better communication between taxonomists and ecologists. Taxon 53 (1): 131-143.

Richardson D.M., Pyšek P., Rejmánek M., Barbour M.G., Panetta F.D., West C.J. 2000. Naturalization and invasion of alien plants: concepts and definitions. Divers. Distrib. 6: 93-107.

Rola J., Rola H. 2010. Solidago spp. biowskaźnikiem występowania odłogów na gruntach rolnych. Fragm. Agron. 27 (3): $122-131$.

Rozporządzenie Ministra Środowiska z dnia 9 września 2011 r. w sprawie listy roślin i zwierząt gatunków obcych, które w przypadku uwolnienia do środowiska przyrodniczego mogą zagrozić gatunkom rodzimym lub siedliskom przyrodniczym. Dz. U. 2004, Nr 210, poz. 1260 .

Solarz W. 2007. Inwazje biologiczne jako zagrożenie dla przyrody. [Biological invasions as a threat for nature]. Prog. Plant Prot./Post. Ochr. Roślin 47 (1): 128-133.

Sowa R., Warcholińska U. 1994. The list of American flowering plant species established in Poland (kenophytes). Thaiszia - J. Bot. Košice 4: 197-210. 
Szczęśniak E. 2004. Sorghum halepense (L.) Pers. (Poaceae) in Wrocław (Lower Silesia, Poland). Acta Bot. Silesiaca 1: 157-159.

Tokarska-Guzik B. 2005. The establishment and spread of alien plant species (kenophytes) in the flora of Poland. Prace Nauk. Uniw. Śląskiego, Katowice 2372, 192 ss.

Tokarska-Guzik B., Węgrzynek B., Urbisz A., Urbisz A., Nowak T., Bzdęga K. 2010. Alien vascular plants in the Silesian Upland of Poland: distribution, patterns, impacts and threats. Biodiv. Res. Conserv. 19: 33-54.

Tokarska-Guzik B., Dajdok Z., Zając M., Urbisz A., Danielewicz W. 2011. Identyfikacja i kategoryzacja roślin obcego pochodzenia jako podstawa działań praktycznych. s. 23-53. W: „Synantropizacja w dobie zmian różnorodności biologicznej” (Z. Kącki, E. Stefańska-Krzaczek, red.). Acta Bot. Silesiaca 6, 248 ss.

Ustawa o ochronie przyrody z dnia 16 kwietnia 2004 r., Dz. U. 2004, Nr 92, poz. 880.

Vandermeer J., Perfecto I. 2007. The agricultural matrix and the future paradigm for conservation. Conservation Biol. 21: $274-277$.

Weber E., Gut D. 2004. Assessing the risk of potentially invasive plant species in central Europe. J. Nature Conservation 12: 171-179.

Williamson M., Fitter A. 1996. The varying success of invaders. Ecology 77: 1661-1666.

Wójcik Z. 2006. Historia powszechna. Wiek XVI-XVII. Wyd. Nauk. PWN, Warszawa, 652 ss. 